\title{
Retirement Planning \& Job Satisfaction: Cushion to Avoid Bridge Employment?
}

\author{
Zaiton Osman ${ }^{1}$, Phang Ing@ Grace ${ }^{1}$, Azaze-Azizi Abd Adis ${ }^{1}$, Izyanti Awg Razli ${ }^{1}$, Mohd Rizwan Abd Majid ${ }^{1}$ \& \\ Imbarine Bujang ${ }^{2}$ \\ ${ }^{1}$ Faculty of Business, Economics \& Accountancy, Universiti Malaysia Sabah, Sabah, Malaysia \\ ${ }^{2}$ Faculty of Business and Management, Universiti Teknologi Mara, Malaysia \\ Correspondence: Zaiton Osman, Faculty of Business, Economics \& Accountancy, Universiti Malaysia Sabah, \\ 88400 Kota Kinabalu, Sabah, Malaysia. Tel: 60-12-969-0204. E-mail: zaiosman@ums.edu.my
}

Received: April 11, 2015 Accepted: May 23, 2015 Online Published: December 21, 2015

doi:10.5539/ass.v12n1p30 URL: http://dx.doi.org/10.5539/ass.v12n1p30

\begin{abstract}
Retirement forces older workers to disconnect with their previous behavioural patterns and economic position. Transition and adjustment from working life to retirement places great psychological pressure and financial distress on older workers, especially those with dependent children. Bridge employment provides a solution for older workers to continue working after retirement while transitioning into retirement slowly and smoothly. As losing the job role has a significant impact on the psychological well-being of retirees, engaging in bridge employment helps to fulfil the important psychological functions of older workers by providing an adaptive style to retirement. This study investigates the influence of retirement planning and job satisfaction on bridge employment. A self-administered questionnaire was used in this study and a total of 523 samples were collected for nine major districts in Sabah. Data were analysed using Partial Least Square (PLS) method version 2.0. The result showed a significant relationship between retirement planning and job satisfaction on bridge employment, explaining $4.7 \%$ the variance in bridge employment and job satisfaction was found to be the strongest predictor of bridge employment.
\end{abstract}

Keywords: ageing population, retirement planning, job satisfaction, bridge employment

\section{Introduction}

Ageing forces changes in a person's life, whether it is from the physical, psychological or the psychosocial aspect. Embarking into retirement, older worker would cease or discontinue from their previous behavioural patterns as well as let go of their economic positions, leading to a process of adjustment and transition (Reis \& Gold, 1993). Having to adjust and transit from an active lifestyle into a slower pace lifestyle will indirectly affect the psychological well-being of retirees. The role loss resulting from retirement transition can cause retirees to feel anxious or depressed, which may lead to low levels of well-being in retirement (Riley \& Riley Jr., 1994). A well-planned pre-retirement will invite a comfortable adjustment and transition into retirement life and a delayed pre-retirement planning among older workers, however, tend to build psychological distress due to having too little monetary saving for retirement (Keating \& Marshall, 1980).

Previous research and reports on retirement funds saved by either the private firms employees as well as government servant in Malaysia concluded that similar amount earned before retirement is need after retirement and saving accumulated prior to retirement is expected to be depleted within five years to 13 years (Othman, 2010; EPF., 2012). Meanwhile, the Department of Statistics (2012) estimated that all Malaysians need to spend an average of 20 years in retirement (based of retirement age of 60 years); hence sole dependence on either government pension funds or Employees Provident Fund (EPF, hereafter) will not provide adequate retirement income for future retirees.

Ageing population is becoming a concern in Malaysia and it is inevitable and therefore, there will not be adequate funds to financially support the retired population in Malaysia if Malaysian were to rely solely on EPF or government funds during retirement. In order to be financially liable, older workers are forced to postpone their retirement and retained in the work force either doing some part-time or temporary work or even full-time employment. Working after retirement either part-time or full-time in the same career field or different field is 
known as bridge employment (Kim \& Feldman, 2000). Bridge employment provides an opportunity for income replacement after retirement as well as psychological comfort before transiting into retirement among older workers. At the same time, as many of today's job are knowledge- or technology-based, this situation permits older workers to continue their career even after retirement age (Miller \& Nyce, 2014). This paper investigates the effect of retirement planning and job satisfaction on bridge employment among working individuals in Malaysia. This paper is organised with first, a brief introduction of the literature review on ageing population in Malaysia and followed by bridge employment, retirement planning and job satisfaction discussed and conducted by previous research. Secondly, this paper introduces the methodology used to investigate the association between retirement planning, job satisfaction and bridge employment. After that, the next section discusses the result tested using Smart PLS and the last part includes conclusion and some recommendation for future research.

\subsection{Ageing Population in Malaysia}

The proportion of Malaysian aged above 60 years is expected to be more than doubled from $7 \%$ of the total population in 2000 to $16 \%$ in 2020 (Department of Statistics, 2010). Between 1990 and 2020, the aged population is expected to increase by $210 \%$, an increase from 1.05 million in 1990 to 3.26 million in 2020 (Mafauzy, 2000). Similarly, the proportion of Malaysia population age 60 and older has increased from 5.2 percent in 1970 to 6.3 percent in 2000 and has been projected to be 9.9 percent in 2020 .

Malaysia is expected to experience a steep increase in the share of elderly persons in the population but at the same time there was a decline in the share of working population and by 2040, one fifth of Malaysians are expected to be in the greater than 60-years bracket (Mafauzy, 2000). This is also shown by the total dependency ratio which is projected to decline from 47.8 to 44.9 for the period of 2010 to 2040 . This trend is affected by the decline in young age dependency ratio from 40.4 to 28.3 while old age dependency ratio is expected to double from 7.4 to 16.6. These ratio proved that the working age population (15 to 64 years old) would have to shoulder the increasing number of old age population. Low birth rates and increased life expectancies are the results of a serious skill shortages in the future, as the ratio between matured aged and younger workers shifts in favour of the ageing segment of the population (Department of Statistics Malaysia, 2010).

Previous studies also found that the effect of ageing will contribute to a disproportionate ratio between men and women as women tend to live longer than men (Mafauzy, 2000; Jasmine Kaur, 2014). The ratio of men per 100 women will decrease from 90.1 in 1990 to 85.8 in 2020. On a contradict note, longer life expectancy especially among female provides opportunities to participate in bridge employment among working population in Sabah. Recognising the importance of older workers and the issues of ageing population, initiatives and efforts by both the Malaysian government and private firms have taken placed in attracting and retaining the older workers in the workforce, including imposing a fine of RM10,000 on employers guilty of requesting an employee to retire prior the age of 60 by the Government of Malaysia as well as recognising the "hard-to-replaced" skills and experience possessed by older workers especially among private firms (Kaur, 2014; Chan, Yeoh, Lim, \& Osman).

\section{Literature Review}

\subsection{Bridge Employment}

The term 'bridge employment' is used by Kim and Feldman (2000) and Shultz, (2003) to refer to the pattern of labour force participation presented by older workers as they leave their career jobs before a complete withdrawal from the labour force. Bridge employment is a potentially valuable asset to the organizations as it can provide experienced and well-trained talents to organization, while these talents are in the process of transition and adjustment to retirement. These older workers can play mentoring positions and guide successors in managing the organization (Maule, 1995; Quinn, Berkhauser, \& Myers, 1990).

As suggested by continuity theory, older workers need to; (1) maintain a daily routine, (2) sustain structure in their daily lives by participating in activities they value highly, (3) seek continuity through some form of work involvement, and (4) sustain a level of satisfying social contact in their old age and by engaging into bridge employment, it will help older workers to gradually transit and adjust into retirement by having fewer working hours and a more unstructured and flexible work condition (Atchley, 1989). Bridge employment engagement is identified to provide three main benefits for older workers, namely, (1) continued activity and daily structure (Atchley, 1989), (2) less-work and less job-related stress (Feldman, 1994) and (3) a better self-worth from having the ability to provide valuable information and guidance to the next generation (Levinson, 1978).

Gobeski and Beehr (2009) suggested that bridge employment can be divided into two main categories, career bridge employment and non-career bridge employment (bridge employment in a different field). Career bridge 
employment engagement may take place either with the same organisation as the career job, which occurs most commonly for career bridge job holders or at a different organization where the individual works in the same occupation (Raymo, Liang, Sugisawa, Kobayashi, \& Sugihara, 2004). When an older worker decided to engage in bridge employment in a different field, they accept a reduced in wages and status, in return for the flexibility of a bridge job (Feldman, 1994; Raymo et al., 2004; Ruhm, 1990; Shultz, 2003). In addition, a study conducted by Jones and McIntosh (2010) indicated that older workers whom were more organizationally focused prefers to engage in bridge employment in the same field, meanwhile those whom were more occupationally focused prefer to engage in bridge employment in a different field. Similarly, bridge employment decision to either embark on career-based or organisation-based is highly influence by skills possessed by older workers, experiences with task and organisation, career and organisational commitments factors, job seeking self-efficacy, perceived subjective norms, positive attitudes as well as work with ease of transition to retirement process (Gobeski \& Beehr, 2009; Lu, 2012; Mariappanadar, 2013; Pengcharoen \& Shultz, 2010; Zhan, Wang, \& Yao, 2013). Retirees with strong entrepreneurial orientation and low organizational tenure tended to take a bridge job in the same field as the career job, and those retirees exhibiting for example, a desire to pursue specific business opportunities or a new career (otherwise known as the "pull" factors) will take a bridge job in a field different from their career job (Davis, 2003).

Previous studies also identified among the important motivators persuading older worker to retain in the workforce which include financial inadequacy, flexible working arrangements, interests outside of work, and management and organisational factors, perception of income inadequacy, firm policies supporting aged employees as well as attitudes towards retirement (Shacklock \& Brunetto, 2011; Zappalà, Depolo, Fraccaroli, Guglielmi, \& Sarchielli, 2008; Winkelmann-Gleed, 2012). Bridge employment is also associated with retirees who are younger in age, have longer tenure with their current employers, have lower salary before retirement and have spouses still in the workforce and have children to support (Kim \& Feldman, 2000).

\subsection{Retirement Planning}

Research conducted by Wang and Shultz (2010), summarised four theoretical conceptualisations of retirement (i.e.; retirement as decision making, retirement as an adjustment process, retirement as career development stage and retirement as part of human resource management) that have been conducted by various researchers over the past 20 years. This research will conceptualise retirement planning as an adjustment process, which refers to the process through which retirees get used to the changed aspects of the transition from working life to achieving satisfaction and psychological comfort in their full-retirement (van Solinge \& Henkens, 2008; Wang, 2007). According to this process, the timing of retirement is not the highlight of the adjustment process, what is more crucial is the pre-retirement preparation, the resources embedded within the process as well as the amount of changed activities that will occur due to the adjustment process. The decision to retire might be similar among older workers but the adjustment into this transition might involve a more complex functional mechanism than the simple retirement decision content (Szinovacs, 2003).

Planning for retirement is not an easy task. Adequate planning requires extensive information and an understanding of the elaborate rules governing social security and pension plans offered by the government (Lusardi, 1999). Lusardi (1999) further confirmed that households who spend time planning for retirement show a significant increase in their savings as compared to those who did not plan for retirement. Financial planning activities could include information seeking activities, for instance, meeting with a financial investment or retirement counsellor (Grable \& Joo, 2001; Richardson, 1990), attending a financial seminar (Lusardi, 2003), or participating in a workplace retirement preparation program (Bernheim \& Garrett, 1996; Madrian \& Shea, 2001) which in turn stimulates saving practices (Gustman \& Steinmeier, 2000).

Past research reported that retirement planning predicts a higher level of post-retirement adjustment across a variety of occupational settings, for instance the public sector (Taylor \& Doverspike, 2003), private sector (Reitzes, Mutran, \& Fernandez, 1996) and military setting (Spiegel \& Shultz, 2003). For instances, a military personnel in Malaysia usually retired at the age of 40 to 45 years old after serving the military not more than 21 years (Peraturan-Peraturan Angkatan Tetap 1982). This situation provides opportunities for retired military personnel to seek other career as they are physically and psychologically capable to continue working. Being prepared and plan for retirement will ensure that these military personnel experience smooth adjustment and transition while continue working by opting for bridge employment or entrepreneurial opportunities.

Western literature also proved that older workers who had prepared for retirement and were ready to make the transition had a higher chance of withdrawing from the workforce at an earlier age (Reitzes et al., 1996; Taylor $\&$ Shore, 1995). Moreover, classic research had also proven that a lack of retirement preparedness will lead to 
the failure of successful retirement adjustment (McPherson \& Guppy, 1979; Teaff \& Johnson, 1983) which forces older workers to remain in the workforce for a longer period of time.

Retirement planning is important for the financial security of an individual as well as for the future retiree's well-being. According to Aiken (2002), retirement planning leads to realistic expectations of retired life and a better degree of preparation with respect to finance and attitudes. Moreover, financial preparation is said to provide satisfaction among retirees (Elder \& Rudolph, 1999). However, many workers are not prepared for retirement simply because they have no clue on how much money they need during retirement (Goldman, 2008; Lusardi \& Mitchell, 2007b). Subsequently, Wang and Shultz (2010), in their work of summarising retirement planning literature noted that the long-term influence of retirement planning on postretirement outcome (i.e.; bridge employment, full-retirement) remains lacking and is relatively unknown. Moreover, a similar research reported that there is a lack of study that explicitly presents how retirement planning may influence postretirement outcomes on the retirement transition process. Based on the review of literature, the authors hypothesize that:

H1 Retirement planning among working individual in Malaysia has a direct positive effect on bridge employment.

\subsection{Job Satisfaction}

Most definition of job satisfaction is quite similar, although they may differ in the conceptualisation of the 'achievement of one's job values'. Job satisfaction or dissatisfaction is a context in which an employee likes or dislikes his or her work. It also has been defined as a general attitude towards one's job as well as one's feelings pertaining to the type of one's work (Ahmad, Ali, Rehman, Aslam Khan, \& Waseemullah, 2010). Mobley and Locke (1970) views job satisfaction and dissatisfaction as constructs of perceived association between an individual's expectations of the job with the actual important values gained from the job.

The classical motivation theories proposed that intrinsic stimulus promote subsequent efforts (Herzberg et al., 1967; Herzberg, 1968). Older workers who are satisfied with their work are more likely to prefer or maintain a positive affective state. Hence, they are less likely to opt for retirement and are more likely to engage into bridge employment (Lim \& Ng, 1997). Subsequently, Straws and Sayles (1980) stated that job satisfaction has been always treated in connection with motivation because of the similarities in them. They also defined job satisfaction as a match between characteristics of the job and the need of the individuals. This is similar to the classic work of Hackman and Oldham (1975), whom proposed the Job Diagnostic Survey (JDS). Employees are expected to either experiences positive internal feeling when working effectively or negative internal feeling when doing the job poorly. Similarly, being satisfied with the current job will provide a higher probability in retaining with the same organization and higher chances of engaging in bridge employment with the same organization (You, Huang, Wang, Liu, Lin, \& Tseng, 2013). Among the main factors that contribute to employees' job satisfaction are job content, wages (Groot \& van Den Brink, 1999), job stability (Ahmad et al., 2010), organisational climate, occupational stress, age and gender (Khan, Ramzan, \& Butt, 2013; Artz, 2012). Hence, it is hypothesized that:

H2 Jos satisfaction among working individual in Malaysia has a positive direct effect on bridge employment.

\section{Methodology}

The respondents selected for this study are working adults from both public and private sector in Sabah, Malaysia as the unit of analysis. Past research has proved that age has a significant effect on what type of retirement outcomes to pursue (Lu, 2012; Templer, Armstrong-Stassen, \& Cattaneo, 2010a; von Bonsdorff, Shultz, Leskinen, \& Tansky, 2009).The respondents are divided based on age group of young-age group (ten years or less of working experience), middle age group (more than ten years of experience and more than 10 years before retirement age) and old age group (less than ten years to retirement). Roscoe's (1975) rule of thumb for determining sample size suggested that a sample size larger than 30 and less than 500 was appropriate for most research. This study also adopted a probability sampling design, i.e. proportionate stratified random sampling. Based on the literature reviews and the conceptual framework, the empirical model for investigating the association between psychological determinants and retirement in predicting bridge employment for this study is as per below;

$$
\mathrm{BE}_{\mathrm{i}}=\alpha+\beta_{1} \mathrm{RP}_{\mathrm{i}}+\beta_{2} \mathrm{JS} \mathrm{S}_{\mathrm{i}}+\varepsilon_{\mathrm{i}}
$$

Where;

$\mathrm{BE}=$ the value of the Bridge Employment (Dependent variable) 
$\alpha=$ Alpha, a constant; equals the value of $\mathrm{BE}$ when the value of independent variables equals to zero

$\beta=$ Beta, the coefficient of independent variables which indicates how much bridge employment changes for each one-unit change in the independent variables.

$\mathrm{RP}=$ the value of Retirement Planning (Independent Variable)

JS $\quad=\quad$ the value of Job Satisfaction (Independent Variable)

$\varepsilon_{\mathrm{i}} \quad=$ the error term; the error in predicting the value of bridge employment, given the value of all the independent variables.

\subsection{Data Collection and Procedures}

This study collected a sample of 550 hundred respondents in two steps. The first step in the selection of respondents was to ensure that the number of respondents selected from nine main districts in Sabah remained proportionate to the total percentage needed from each strata or district. Data was collected via a self-administered survey instrument in major towns in Sabah. The selected locations were the major districts of Sabah namely, Kudat, Ranau, Kota Kinabalu, Beaufort, Sandakan, Tawau, Keningau, Semporna and Lahad Datu.

The second step in the sampling process was to stratify and divide the respondents into three age categories, i.e. (i) young age, (ii) middle age and (iii) old age. The young age category referred to working adults with ten years or less of working experience, while, middle age referred to working adults with more than ten years of experience and more than 10 years before retirement age. The last category of old age referred to working adults with less than ten years to retirement. This study decided to divide the age group categories into three different groups based on the past researchers' work that found age to have a significant effect on bridge employment. As indicated by previous research, older individuals were less likely to plan to engage in bridge employment than younger people (von Bonsdorff et al., 2009) due to the fact that age has an indisputable effect on the employees' ability to continue working. Stratifying the sample based on the age factor would provide a significant generalisation on the Sabah population. Based on the number of respondents required from each district and age group, respondents were then randomly drawn from the list of future pensioners obtained from the Department of Civil Servants and major private organizations in Sabah.

\subsection{Measurement and Assessment of Goodness of Measure}

A survey instrument via a self-administered questionnaire using a five-point Likert scale was used in this research. Questions for this study were adopted and adapted from past established research in the area of bridge employment, retirement planning and job satisfaction, which had been separately tested in a different environment, which further strengthened its content and criterion-related validity (Davies \& Cartwright, 2011; Hackman \& Oldham, 1974; Hershey \& Mowen, 2000).

\subsection{Goodness of Measures}

The two main criteria used for testing goodness of measures are validity and reliability. Validity of a scale refers to the degree to which it measures what it is supposed to measure and reliability indicates stability and consistency in terms of measuring the concepts and providing an assessment on the 'goodness' of a measure (Sekaran \& Bougie, 2010).

\subsection{Construct Validity}

Construct validity testifies to how well the results obtained from the use of the measure fit the theories around which the test is design (Sekaran \& Bougie, 2010). The first process of construct validity is to look the respective loadings and cross loadings from Table 1 to assess if there are problems with any particular items. The authors used a cut-off value for loadings at 0.5 as significant (Hair et al., 2010). If any items which has a loading of higher than 0.5 on two or more factors then it is considered as significant cross loadings. In this study, it is observed that all the items measuring the particular construct loaded highly on the construct and loaded lower on the other constructs thus conforming construct validity.

\subsection{Convergent Validity}

As suggested by Hair et al. (2010), factor loadings, composite reliability and average variance extracted from the study to measure its convergent validity. The loadings for all items exceeded the recommended value of 0.5 (Hair et al., 2010). Composite reliability value (refer to Table 2), which depict the degree to which the construct indicators indicate the latent, range from 0.537 to 0.881 which exceeded the recommended value of 0.5 (Hair et al, 2010). The average variance extracted (AVE) measures the variance captured by the indictors relative to measurement error, and it should be greater than 0.50 to justify using a construct (Barclay et al., 1995). The 
average variance extracted, were in the range 0.507 to 0.529 .

Table 1. Loadings and cross loadings

\begin{tabular}{cccc}
\hline & Bridge Employment & Job Satisfaction & Retirement Planning \\
\hline BridgeE1 & $\mathbf{0 . 6 5 9 3 5 3}$ & 0.015509 & 0.090886 \\
BridgeE2 & $\mathbf{0 . 6 6 6 7 6 2}$ & 0.036365 & 0.134273 \\
BridgeE4 & $\mathbf{0 . 6 1 1 4 9 2}$ & 0.018247 & 0.063326 \\
BridgeE5 & $\mathbf{0 . 8 8 1 4 0 4}$ & 0.231667 & 0.135528 \\
JobS1 & 0.08282 & $\mathbf{0 . 6 6 9 0 4 2}$ & -0.010138 \\
JobS4 & 0.109311 & $\mathbf{0 . 6 2 6 1 1 4}$ & 0.190324 \\
JobS6 & 0.160796 & $\mathbf{0 . 8 4 0 3 8}$ & 0.127336 \\
RetirePLan5 & 0.163259 & 0.128304 & $\mathbf{0 . 8 3 7 9 7 3}$ \\
RetirePlan2 & 0.115988 & 0.096827 & $\mathbf{0 . 7 9 9 9 2 4}$ \\
RetirePlan3 & 0.137099 & 0.092372 & $\mathbf{0 . 8 2 6 6 3 1}$ \\
RetirePlan4 & 0.10478 & 0.109555 & $\mathbf{0 . 6 7 6 7 4 5}$ \\
RetirePlan6 & 0.089091 & 0.190324 & $\mathbf{0 . 7 5 9 5 2 8}$ \\
RetirePlan7 & 0.101011 & 0.058625 & $\mathbf{0 . 7 0 0 4 1}$ \\
RetirePlan8 & 0.074555 & 0.184621 & $\mathbf{0 . 5 3 6 7 5 1}$ \\
RetirePlan9 & 0.007195 & 0.031088 & $\mathbf{0 . 6 2 6 5 4 3}$
\end{tabular}

Bold values are loadings with are above the recommended value of 0.5

\subsection{Discriminant Validity}

The discriminant validity (the degree to items differentiate among construct or measure distinct concepts) was measured by examining the correlations between the measures of potential overlapping constructs. Items should load more strongly on their own constructs in the model, and the average variance shared between each construct and its measure should be greater than the variance shared between the construct and other constructs (Compeau et al., 1999). As shown in Table 3, the squared correlation for each construct are less than the average variance extracted by the indicators measuring the construct indicating adequate discriminant validity. In total, the measurement model demonstrated adequate convergent validity and discriminant validity.

Table 2. Results of measurement model

\begin{tabular}{ccccc}
\hline Model Construct & Measurement Items & Loading & CR $^{\mathrm{a}}$ & AVE $^{\mathrm{b}}$ \\
\hline Bridge Employment & BridgeE1 & 0.659353 & 0.801357 & 0.507528 \\
& BridgeE2 & 0.666762 & & \\
& BridgeE4 & 0.611492 & & \\
Job Satisfaction & BridgeE5 & 0.881404 & & \\
& JobS1 & 0.669042 & 0.758236 & 0.515292 \\
\multirow{3}{*}{ Retirement Planning } & JobS4 & 0.626114 & & \\
& JobS6 & 0.84038 & & \\
& RetirePLan5 & 0.837973 & 0.8989143 & \\
& RetirePlan2 & 0.799924 & & \\
& RetirePlan3 & 0.826631 & & \\
& RetirePlan4 & 0.676745 & & \\
\hline
\end{tabular}




$\begin{array}{lc}\text { RetirePlan6 } & 0.759528 \\ \text { RetirePlan7 } & 0.70041 \\ \text { RetirePlan8 } & 0.536751 \\ \text { RetirePlan9 } & 0.626543\end{array}$

${ }^{\text {a }}$ Composite Reliability $(\mathrm{CR})=$ (square of the summation of the factor loadings)/ (square of the summation of the factor loadings) + (square of the summation of the error variances) $\}$

${ }^{\mathrm{b}}$ Average Variance Extracted $(\mathrm{AVE})=$ (summation of the square of the factor loadings) $/$ ( (summation of the square of the factor loadings) + (summation of the error variances) $\}$

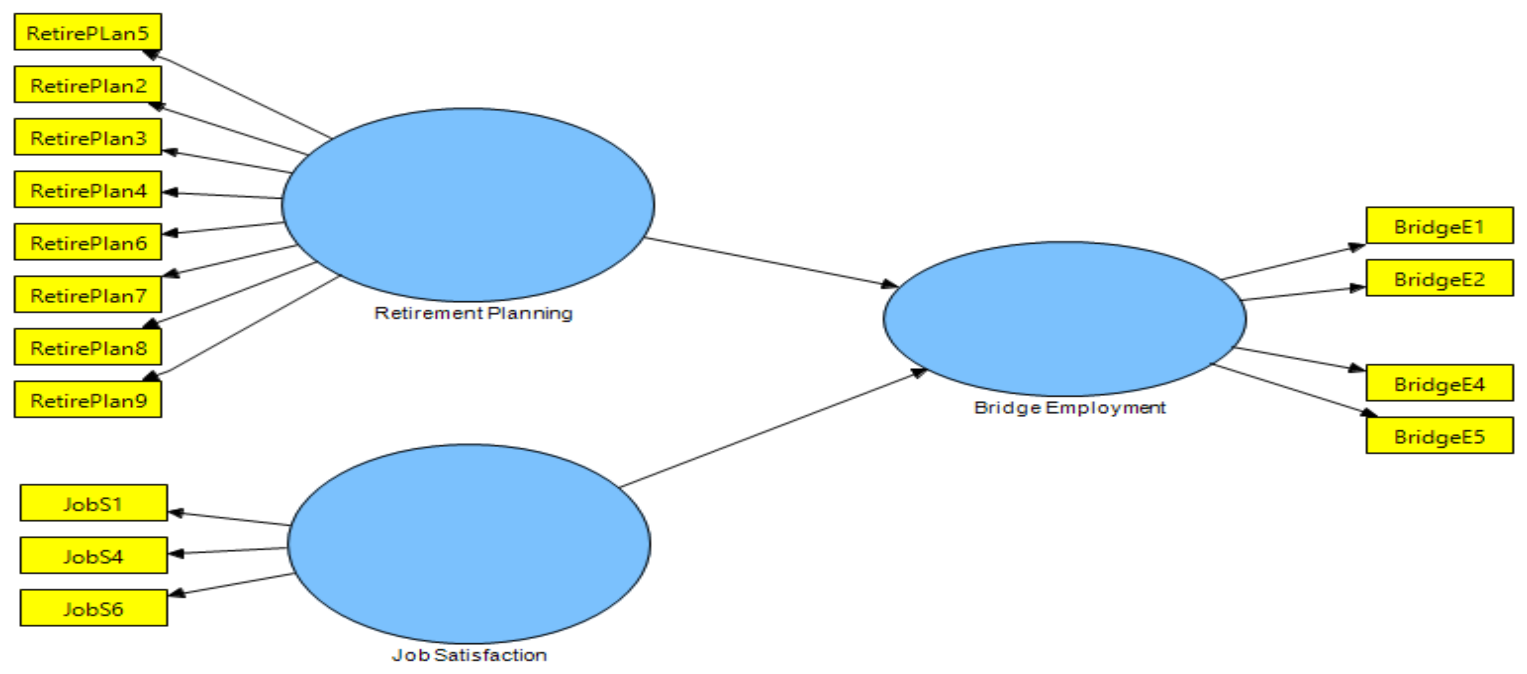

Figure 1. Research model

\subsection{Structural Model}

The structural model represent the relationship between construct or latent variables that were hypothesized in the research model. The goodness of the theoretical model is established by the variance explained $\left(\mathrm{R}^{2}\right)$ of the endogenous construct and the significance of all path estimates (Chin, 2010). Together the $R^{2}$ and the path coefficient indicate how well the data support the hypothesized model (Chin, 1998). Figure 1 and Table 3 shows the results of structural model from Smart PLS output. Retirement planning was found to be significantly related to bridge employment $(\beta=0.133, p<0.05)$ and similarly, job satisfaction was also found to be significantly associated with bridge employment $(\beta=0.152, p<0.05)$, thus supporting $\mathrm{H}_{1}$ and $\mathrm{H}_{2}$ of this study. Looking closer at the results showed that job satisfaction is a stronger predictor to bridge employment as compared to retirement planning.

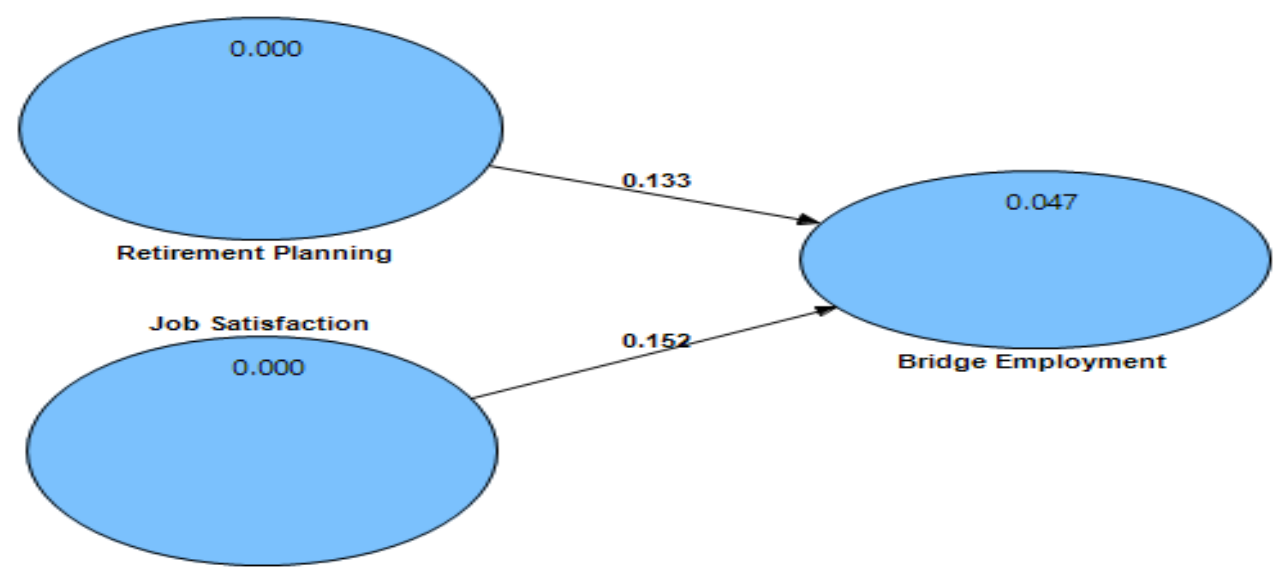

Figure 2. Structural model 
Table 3. Summary of the structural model

\begin{tabular}{cccccc}
\hline Path & Hypotheses & Path Coefficient & Standard Error & t-value & Results \\
\hline Retirement Planning -> Bridge Employment & $\mathrm{H}_{1}$ & 0.133217 & 0.042890 & $3.106^{* *}$ & Supported \\
Job Satisfaction -> Bridge Employment & $\mathrm{H}_{2}$ & 0.151656 & 0.081928 & $1.851^{*}$ & Supported \\
\hline
\end{tabular}

\section{Discussion and Conclusion}

The purpose of this study is to investigate the effect of retirement planning and job satisfaction on bridge employment among working individual in Sabah, Malaysia. The results from this study supported the theory of continuity, which posits that an individual's identity and self-concept do not differ greatly before and after retirement, or during the retirement transition. Continuing to work in retirement is consistent with continuity during the retirement transition. the importance of planning in retirement-related decision making, and noted that retirees are said to be motivated in maintaining continuity, and to improve their own satisfaction and well-being by engaging into similar form of work activities before their retirement. As reported by Taylor-Carter, Cook, and Weinberg (1997) an individual who engages in retirement planning tend to report less anxiety and depression about retirement, greater confidence about managing the transition to retirement and better adjustment, satisfaction (Rosenkoetter \& Garris, 2001; Spiegel \& Shultz, 2003) and well-being once retired (Noone, Stephens, \& Alpass, 2009).

Moreover, one classic study found that retirees' decisions to engage in bridge employment will be influenced by their desire to closely approximate their current standards of living after leaving their full-time jobs (Daniels \& Daniels, 1991). Similarly, retirees may decide to view retirement as another logical career stage (Quick \& Moen, 1998) and maintain the same life routine or schedule as before (Kim \& Feldman, 2000), participate in leisure activities and sustain levels of social contact (Pushkar et al., 2009; Harlow \& Cantor, 1996), maintain a stable self-concept (Troll \& Skaff, 1997); or continue to work (Kim \& Feldman, 2000). This study shows that even though the respondents perceived retirement planning as an important tool for retirement, they also posits that doing the right retirement planning will open opportunities for them to continue working in other area such as entrepreneurship. Planning for retirement helps to guide them in the direction of business which might or might not be different from their current career employment.

Past research on retirement and job satisfaction proved that individuals who are satisfied with their career jobs might be willing to engage into bridge employment if the job is similar to their career job (Gobeski \& Beehr, 2009). However, results from past research on retirement planning and job satisfaction based on different studies and different samples, were inconsistent. Gobeski and Beehr (2009) concluded that without examining the role played by bridge employment, researchers would not know why this inconsistency exists. The result from this study may shed some lights on such inconsistency.

The result from this study shows that job satisfaction plays an essential role in its association with bridge employment. This indicates that if an individual is satisfied with his/her job and also plans for his/her retirement, there is a high chance of him/her engaging into bridge employment. This result proved that job satisfaction plays a crucial role in encouraging the willingness to engage in bridge employment among older workers despite the different bridge employment options. Similar research conducted by Gobeski and Beehr (2009) found that when the retirees were satisfied with their career jobs, they were more likely to take a bridge employment in the same career. They concluded that favourable reactions to career job were related to taking a bridge employment that is in the same field as that of the career job; while unfavourable reactions to the career job were related to taking a bridge employment in a different field (Gobeski \& Beehr, 2009).

As a conclusion, this study is conducted to investigate the association between retirement planning and job satisfaction with bridge employment. This study proved that both variables are predictors to bridge employment. However, this study is not without flaws. This study is based on cross sectional self-reported data pertaining to attitudes towards perceived bridge employment and preferences towards bridge employment rather than measuring actual behaviour. Longitudinal study should be conducted in order to measure the actual attitudes and behaviour is being measured towards bridge employment. This study is also limited in terms of geographical and sample which was targeted at working individual at large, in the state of Sabah, Malaysia. A study which include larger coverage of area as well as specific economic sector should be conducted so that which sector of economy that is in need of bridge employment can be easily identified. 


\section{References}

Ahmad, S., Ali, I., Rehman, K. ur., Aslam Khan, M., \& Waseemullah. (2010). Insecure Job and Low Pay leads to Job Dissatisfaction. Interdisciplinary Journal of Comtemporary Research in Business, 1(11), 90-103. Retrived from http://xa.yimg.com/kq/groups/22240048/1814310405/name/article-ijcrb.pdf

Aiken, L. R. (2002). Attitudes and related psychosocial constructs: theories, assessment, and research (pp. 183-207). Thousand Oaks, CA: Sage.

Artz, B. (2012). Does the Impact of Union Experience on Job Satisfaction Differ by Gender? ILRReview, 65(April), 225-243. http://dx.doi.org/10.1177/001979391206500202

Atchley, R. C. (1989). A Continuity Theory of Normal Ageing. The Gerontologist, 29(2), 183-190. http://dx.doi.org/10.1093/geront/29.2.183

Beehr, T. A. (1986). The process of retirement : a review and recommendations for future. Personnel Psychology, 39, 31-56. http://dx.doi.org/10.1111/j.1744-6570.1986.tb00573.x

Bernheim, D., \& Garrett, D. (1996). The determinants and consequences of financial education in workplace. Evidence from a survey of households (No. \#96-007) (pp. 1-54). Stanford. http://dx.doi.org/10.3386/w5667

Buyens, D., Dijk, H. Van, Dewilde, T., \& Vos, A. De. (2009). The ageing workforce: perceptions of career ending. Journal of Managerial Psychology, 24(2), 102-117. http://dx.doi.org/10.1108/02683940910928838

Chin, W. W. (1998). The partial least squares approach to structural equation modeling. In G. A. Marcoulides (Ed.), Modern business research methods. Mahwah, NJ: Lawrence Erlbaum Associates.

Chin, W. W. (2010). How to write up and report PLS analyses. In V. Esposito Vinzi, W. W. Chin, J. Henseler, \& H. Wang (Eds.), Handbook of partial least squares: Concepts, methods and applications. Berlin, Germany: Springer-Verlag. http://dx.doi.org/10.1007/978-3-540-32827-8_29

Compeau, D. R., Higgins C. A., \& Huff, S. (1999). Social cognitive theory and individual reactions to computing technology: a longitudinal-study. MIS Quarterly, 23(2), 145-158, http://dx.doi.org/10.2307/249749

Davies, E., \& Cartwright, S. (2011). Psychological and psychosocial predictors of attitudes to working past normal retirement age. Employee Relations, 33(3), 249-268. http://dx.doi.org/10.1108/01425451111121768

Davis, M. A. (2003). Factors related to bridge employment participation among private sector early retirees. Journal of Vocational Behavior, 63(1), 55-71. http://dx.doi.org/10.1016/S0001-8791(02)00016-7

Department of Statistics, M. (2010). Labor force statistics, Malaysia, 2010 (pp. 4-9). Kuala Lumpur.

Department of Statistics, M. (2012). Household income and basic amenities survey report (pp. 1-133). Kuala Lumpur, Malaysia.

Ekerdt, J., Hackney, J., Kosloski, K., \& DeViney, S. (2001). Eddies in the stream: the prevalence of uncertain plans for retirement. The Journals of Gerontology. Series B, Psychological Sciences and Social Sciences, 56(3), S162-170. Retrieved from http://www.ncbi.nlm.nih.gov/pubmed/11316841

Elder, H., \& Rudolph, P. (1999). Does retirement planning affect the level of retirement satisfaction? Financial Services Review, 8, 117-127. http://dx.doi.org/10.1016/s1057-0810(99)00036-0

EPF. (2012). EPF quarterly performance indicator 2012 ( operations ). Annual Report, 2012, 2011-2012.

Feldman, D. C. (1994). The Decision to Retire Early: A Review and Conceptualization. The Academy of Management Review, 19(2), 285-311. http://dx.doi.org/10.2307/258706

Glass, J. C., \& Flynn, D. K. (2000). Retirement Needs and Preparation of Rural Middle-Aged Persons. Educational Gerontology, 26(2), 109-134. http://dx.doi.org/10.1080/036012700267286

Gobeski, K. T., \& Beehr, T. A. (2009). How retirees work : predictors of different types of bridge employment y. Journal of Organizational Behavior, 425(May 2006), 401-425. http://dx.doi.org/10.1002/job

Goldman, D. (2008). Most Americans unprepared for retirement. CNNMoney.com. Retrieved from http://money.cnn.com/2008/02/19/pf/retirement/crr_healthcare/

Grable, J. E., \& Joo, S. (2001). A Further Examination of Financial Help-Seeking Behavior. Financial Counseling and Planning, 12(1), 55-74. Retrieved from http://6aa7f5c4a9901a3e1a1682793cd11f5a6b732 d29. gripelements.com/pdf/vol1215.pd

Groot, W., \& van Den Brink, H. M. (1999). Job satisfaction of older workers. International Journal of Manpower, 20(6), 343-360. http://dx.doi.org/10.1108/01437729910289701 
Gustman, A. L., \& Steinmeier, T. L. (2000). Retirement Outcomes in the Health and Retirement Study (No. w7588) (pp. 1-44). Cambridge, MA. http://dx.doi.org/10.3386/w7588

Hackman, J. R., \& Oldham, G. R. (1975). Development of the Job Diagnostic Survey. Journal of Applied Psychology, 60(2), 159-170. http://dx.doi.org/10.1037/h0076546

Hair, J. F., Black, W. C., Babin, B. J., \& Anderson, R. E. (2010). Multivariate data analysis. Prentice-Hall, Upper Saddle River

Hershey, D. A., \& Mowen, J. C. (2000). Psychological determinants of financial preparedness for retirement. The Gerontologist, 40(6), 687-697. Retrieved from http://www.ncbi.nlm.nih.gov/pubmed/11131085

Herzberg, F. (1968). One more time: How do you motivate employees? Harvard Business Review, 46(1), 53-62. http://dx.doi.org/10.1007/978-1-349-02701-9_2

Herzberg, F., Mausner, B., \& Snyderman, B. (1967). The motivation to work (2nd ed.). New York: Wiley.

Jasmin, K. (2014). How to attract mature workforce? Retrieved from http://my.jobsdb.com/MY/EN/Resources/ EmployerArticle/howtoattractmatureworkforce?ID $=1062$

Jones, D. A., \& McIntosh, B. R. (2010). Organizational and occupational commitment in relation to bridge employment and retirement intentions. Journal of Vocational Behavior, 77(2), 290-303. http://dx.doi.org/10.1016/j.jvb.2010.04.004

Keating, N., \& Marshall, J. (1980). The process of retirement: the rural self employed. Gerontologist, 20(4), 437-443. doi : 10.1093/geront/20.4.437

Khan, A., Ramzan, M., \& Butt, M. S. (2013). Is job satisfaction of islamic banks operational staff determined through organizational climate, occupational stress, age and gender. Journal of Business Studies Quarterly, 4(3), 11-26. Retrieved from www.superior.edu.pk/images/research/23.pdf

Kim, S., \& Feldman, D. (2000). Working in retirement: The antecedents of bridge employment and its consequences for quality of life in retirement. Academy of Management Journal, 43(6), 1195-1210. http://dx.doi.org/10.2307/1556345

Levinson, D. J. (1978). The season's of a man's life. New York: Knopf.

Lim, G. S., \& Ng, L. T. (1997). Early retirement and bridge employment intentions among older workers in Singapore. Asia Pacific Journal of Management, 14(2), 185-210. http://dx.doi.org/10.1023/a:101540580 3415

Lu, L. (2012). Attitudes towards ageing and older people's intentions to continue working: a Taiwanese study. Career Development International, 17(1), 83-98. http://dx.doi.org/10.1108/13620431211201346

Lusardi, A. (1999). Informations, expectations and savings for retirement. In Behavioral dimensions of retirement economics. Washington, DC: Brookings Institution Press and Russell Sage Foundation.

Lusardi, A. (2003). The impact of financial education on savings and asset allocation (No. WP 2003-061) (pp. 1-64). Retrieved from http://ssrn.com/abstract=1092150

Lusardi, A., \& Mitchell, O. S. (2007, January). Financial literacy and retirement preparedness : Evidence and implications for financial education. Business Economics, (January), 35-44. http://dx.doi.org/10.2145/20070 104

Madrian, B. C., \& Shea, D. F. (2001). The Power of Suggestion: Inertia in 401(k) Participation and Savings Behavior. The Quarterly Journal of Economics, 116(4), 1149-1187. http://dx.doi.org/10.1162/0033553017 53265543

Mafauzy, M. (2000). The problems and challanges of the ageing population. Malaysian Journal of Medical Sciences, 7(1), 7-9. Retrieved from http://journal.usm.my/journal/MJMS-7-1-001.pdf

Mariappanadar, S. (2013). Do retirement anxieties determine bridge employment preference?: A study among pre-retirees in the Australian construction industry. Personnel Review, 42(2), 176-204. http://dx.doi.org/ $10.1108 / 00483481311309375$

Maule, A. J. (1995). Early retirement schemes: Factors governing their success and how these differ across job categories. Personnel Review, 24(8), 6-16. http://dx.doi.org/10.1108/00483489510099541

McPherson, B., \& Guppy, N. (1979). Pre-retirement Life-style and the Degree of Planning for Retirement. Journal of Gerontology, 34(2), 254-263. http://dx.doi.org/10.1093/geronj/34.2.254 
Miller, BJ., \& Nyce, S.(2014). Which workers are delaying retirement and why? Insider, 1-8. Retrieved from http://www.towerswatson.com/en/Insights/Newsletters/Americas/Insider/2014/which-employees-are-delayi ng-retirement-and-why

Mobley, W. H., \& Locke, E. A. (1970). The relationship of value importance to satisfaction. Organizational Behavior and Human Performance, 5(5), 463-483. http://dx.doi.org/10.1016/0030-5073(70)90035-8

Noone, J. H., Stephens, C., \& Alpass, F. M. (2009). Preretirement planning and well-being in later life: a prospective study. Research on Ageing, 31(3), 295-317. http://dx.doi.org/10.1177/0164027508330718

Othman, S. H. (2010). Malaysia's pension system current status, issues and way forward (pp. 1-20). Kuala Lumpur.

Pengcharoen, C., \& Shultz, K. S. (2010). The influences on bridge employment decisions. International Journal of Manpower, 31(3), 322-336. http://dx.doi.org/10.1108/01437721011050602

Peraturan-Peraturan Angkatan Tetap 1982. (1982). Majlis Angkatan Tentera, Malaysia.

Quick, H., \& Moen, P. (1998). Gender, employment, and retirement quality: a life course approach to the differential experiences of men and women. Journal of Occupational Health Psychology, 3(1), 44-64. Retrieved from http://www.ncbi.nlm.nih.gov/pubmed/9552271

Quinn, J. F., Berkhauser, R. V., \& Myers, D. A. (1990). Introduction. Passing the torch: the influence of economic incentives on work and retirement. Kalamazoo, MI: Upjohn Institute of Employment Research. http://dx.doi.org/10.1177/1757975914521369

Raymo, J. M., Liang, J., Sugisawa, H., Kobayashi, E., \& Sugihara, Y. (2004). Work at older ages in Japan: variation by gender and employment status. The Journals of Gerontology. Series B, Psychological Sciences and Social Sciences, 59(3), S154-63. Retrieved from http://www.ncbi.nlm.nih.gov/pubmed/15118021

Reis, M., \& Gold, D. (1993). Retirement, personality, and life satisfaction: a review and two models. Journal of Applied Gerontology, 12(2), 261-282. http://dx.doi.org/10.1177/073346489301200209

Reitzes, D. C., Mutran, E. J., \& Fernandez, M. E. (1996). Preretirement influences on postretirement self-esteem. The Journals of Gerontology. Series B, Psychological Sciences and Social Sciences, 51(5), S242-9. Retrieved from http://www.ncbi.nlm.nih.gov/pubmed/8809009

Reitzes, D., \& Mutran, E. (2004). The transition to retirement: stages and factors that influence retirement adjustment. International Journal of Ageing \& Human Development, 59(1), 63-84. Retrieved from http://www.ncbi.nlm.nih.gov/pubmed/15453412

Richardson, V. (1990). Gender differences in retirement planning among educators : Journal of Woman \& Ageing, 2(3), 27-40. http://dx.doi.org/10.1300/J074v02n03

Riley, M. W., \& Riley, J. W. Jr. (1994). Structural lag: past and future. In M. W. Riley, R. L. Kahn, A. Foner, \& K. A. Mack (Eds.), Age and structural lag: Society's failure to provide meaningful opportunities in work, family, and leisure. (pp. 15-36). Oxford, England: John Wiley \& Sons.

Rosenkoetter, M., \& Garris, J. (2001). Retirement planning, use of time, and psychosocial adjustment. Issues in Mental Health Nursing, 22, 703-722. http://dx.doi.org/10.1080/016128401750434491

Ruhm, C. J. (1990). Bridge Jobs and Partial Retirement. J LABOR ECON, 8(4), 482. http://dx.doi.org/10.1086/ 298231

Sekaran, U., \& Bougie, R. (2010). Research methods for business: a skill building approach (5th ed.). United Kingdom: John Wiley and Sons Ltd.

Shacklock, K., \& Brunetto, Y. (2011). A model of older workers' intentions to continue working. Personnel Review, 40(2), 252-274. http://dx.doi.org/10.1108/00483481111106110

Sharpley, C. F., \& Layton, R. (1998). Effects of age of retirement, reason for retirement, and pre-retirement training on psychological and physical health during retirement. Australian Psychologist, 33(2). http://dx.doi.org/10.1080/00050069808257392

Shultz, K. S. (2003). Bridge employment: work after retirement. In G. A. Adams, \& T. A. Beehr (Eds.), Retirement: Reasons, processes, and results (pp. 214-241). Springer Publishing Company, Inc New York, NY.

Spiegel, P. E., \& Shultz, K. S. (2003). The influence of preretirement planning and transferability of skills on naval officers retirement satisfaction and adjestment.pdf. Military Psychology, 15(4), 285-307. 
http://dx.doi.org/10.1207/s15327876mp1504_3

Straws, G., \& Sayles, L. R. (1980). Personnel: the human problem of management (p. 198). New Jersey: Prentice Hall.

Szinovacs, M. E. (2003). Content and pathway: retirement as institution, process and experience. In G. A. Adams, \& T. Beehr (Eds.), Retirement: reasons, process and results (pp. 6-52). New York, NY: Springer.

Taylor, M. A., \& Doverspike, D. (2003). Retirement planning and preparation. In Retirement: Reasons, processes, and results (pp. 53-82). New York: Springer Publishing Company.

Taylor, M. A., \& Shore, L. M. (1995). Predictors of planned retirement age: an application of Beehr's model. Psychology and Ageing, 10(1), 76-83. Retrieved from http://www.ncbi.nlm.nih.gov/pubmed/7779319

Taylor-Carter, M. A., Cook, K., \& Weinberg, C. (1997). Planning and expectations of the retirement experience. Educational Gerontology, 23(3), 273-288. http://dx.doi.org/10.1080/0360127970230306

Teaff, J. D., \& Johnson, D. C. (1983). Preretirement education: a proposed bill for tuition tax credit. Educational Gerontology, 9(1), 31-36. http://dx.doi.org/10.1080/0380127830090103

Templer, A., Armstrong-Stassen, M., \& Cattaneo, J. (2010). Antecedents of older workers' motives for continuing to work. Career Development International, 15(5), 479-500. http://dx.doi.org/10.1108/136204 31011075349

Van Solinge, H., \& Henkens, K. (2008). Adjustment to and satisfaction with retirement: two of a kind? Psychology and Ageing, 23(2), 422-434. http://dx.doi.org/10.1037/0882-7974.23.2.422

Von Bonsdorff, M., Shultz, K., Leskinen, E., \& Tansky, J. (2009). The choice between retirement and bridge employment: a continuity theory and life course perspective. The International Journal of Ageing and Human Development, 69(2), 79-100. http://dx.doi.org/10.2190/AG.69.2.a

Wang, M., \& Shultz, K. (2010). Employee retirement: a review and recommendations for future investigation. Journal of Management, 36(1), 172-206. http://dx.doi.org/10.1177/0149206309347957

Winkelmann-Gleed, A. (2012). Retirement or committed to work?: Conceptualising prolonged labour market participation through organisational commitment. Employee Relations, 34(1), 80-90. http://dx.doi.org/10.1108/01425451211183273

Wong, J. Y., \& Earl, J. K. (2009). Towards an integrated model of individual, psychosocial, and organizational predictors of retirement adjustment. Journal of Vocational Behavior, 75(1), 1-13. http://dx.doi.org/10.1016/j.jvb.2008.12.010

Yin-Fah, B. C., Foon, Y. S., Chee-Leong, L., \& Osman, S. (2010). An Exploratory Study on Turnover Intention among Private Sector Employees. International Journal of Business and Management, 5(8), 57, http://dx.doi.org/10.5539/ijbm.v5n8p57

You, C. S., Huang, C. C., Wang, H. B., Liu, K. N., Lin, C. H., \& Tseng, J. S. (2013). The Relationship between Corporate Social Responsibility, Job Satisfaction and Organizational Commitment. International Journal of Organizational Innovation, 5(4), 65-77.

Zappalà, S., Depolo, M., Fraccaroli, F., Guglielmi, D., \& Sarchielli, G. (2008). Postponing job retirement?: Psychosocial influences on the preference for early or late retirement. Career Development International, 13(2), 150-167. http://dx.doi.org/10.1108/13620430810860558

Zhan, Y., Wang, M., \& Yao, X. (2013). Domain specific effects of commitment on bridge employment decisions: The moderating role of economic stress. European Journal of Work and Organizational Psychology, 22(3), 362-375. http://dx.doi.org/10.1080/1359432X.2012.762763

\section{Copyrights}

Copyright for this article is retained by the author(s), with first publication rights granted to the journal.

This is an open-access article distributed under the terms and conditions of the Creative Commons Attribution license (http://creativecommons.org/licenses/by/3.0/). 